Walisongo Law Review (Walrev), Vol 3 No. 1 (2021)

DOI: 10.21580/walrev/2021.3.1.8078

Copyright (C) 2021 Walisongo Law Review (Walrev)

\title{
Joint Property Distribution Upon Divorce Reviewed from the Contribution of Husband and Wife in the Household
}

\author{
Eka Ristianawati \\ Affiliation: Universitas Islam Negeri (UIN) Walisongo, Semarang \\ Email: ekaristiana@walisongo.ac.id
}

\begin{abstract}
Joint property distribution has been regulated in the Islamic Law Compilation (KHI), namely, Article 97 which explains that a widow or widower is entitled to half of the joint property. The distribution is fair if the husband and wife make the same contribution in the marriage. However, in fact, today we often find that wives are being the backbone of the family while husbands do not earn a living or husbands earn a living for the family, but wives do not take care of the household. If such a situation is found, is the article 97 of KHI still relevant? This paper presents a concept of joint property distribution based on the contribution of husband and wife in marriage which is considered fairer for both of them than what has been stipulated in the KHI and the Civil Code Articles 128-129. The type of research used is descriptive research. This means that research is discussed in the form of an explanation described in words carefully and thoroughly. The approach method used in this research is a normative juridical approach. The results of this study explain that to obtain the justice, judges can act contra legem (against the law) where justice should give a share to everyone based on his services or contributions. The joint property distribution in marriage from a justice perspective is the
\end{abstract}


distribution of joint property by assessing the amount of contribution of the parties. A fair share does not have to be $50 \%$ for widowers and $50 \%$ for widows. The husband can get a smaller share from the wife if the contribution is less during the marriage and does not carry out his obligation as the breadwinner and the wife can get a larger share from the husband if the wife plays a dual role, and vice versa.

Pembagian harta bersama telah diatur dalam Kompilasi Hukum Islam yakni pada pasal 97 dijelaskan bahwajanda atau duda berhak separuh dari harta bersama. Pembagian tersebut adil apabila suami dan istri memberikan kontribusi yang sama dalam perkawinan. Akan tetapi pada faktanya saat ini sering kita temui istri menjadi tulang punggung keluarga sedangkan suami tidak mencari nafkah atau suami mencari nafkah untuk keluarga akan tetapi istri tidak mengurus rumah tangga. Jika ditemukan keadaan seperti itu apakah masih relevan KHI pasal 97 tersebut. Tulisan ini menyajikan sebuah konsep pembagian harta bersama berdasarkan kontribusi suami istri dalam perkawinan yang dinilai lebih adil untuk keduanya daripada apa yang sudah diatur dalam KHI dan KUHPerdata Pasal 128129. Hasil dari penelitian ini dijelaskan bahwa untuk mendapatkan sebuah keadilan hakim dapat bertindak contra legem (mengenyampingkan undang-undang) dimana keadilan itu seharusnya memberikan bagian kepada setiap orang didasarkan atas jasa-jasanya atau kontribusinya. Pembagian harta bersama dalam perkawinan jika dilihat dari perspektif keadilan adalah pembagian harta bersama dengan menilai besaran konstribusi para pihak. Dimana pembagian yang adil tidak harus $50 \%$ untuk duda dan 50\% untuk janda. suami bisa mendapatkan bagian yang lebih kecil dari istri apabila kontribusinya kurang selama perkawinan dan tidak menjalankan kewaibannya sebagai pencari nafkah dan istri bisa mendapatkan bagian yang lebih besar dari suami jika istri berperan ganda, begitu uga sebaliknya.

Keywords: joint property; justice; marriage. 


\section{Introduction}

Marriage does not only unite a man and a woman in a house or family, but it also has legal consequences for husband and wife. In principle, the purpose of marriage is to last forever and to provide pleasure and happiness for the husband and wife. But, in fact, there are many factors that trigger marital rift. A marriage breakup will cause legal consequences which are the consequences of husband and wife relationship. The legal consequences that arise are child custody (hadhonah), 'iddah income, and mut'ah, wife's iddah period, wife's and children's livelihood, and joint property.

Joint property is the result of a family legal relationship, so the two cannot be separated. The distribution of joint property between husband and wife after divorce is one of the complicated issues. This causes many lawsuits for joint property after the divorce. Regarding the joint property distribution or gono gini, article 97 of Compilation of Islamic Law states: "Widow or widower each is entitled to one-half of the joint property as long as it is not specified otherwise in the marriage agreement." Then, Article 128-129 of the Civil Code states that if a marriage is over between husband and wife, the joint property is divided in half between husband and wife (Pemerintah Republik Indonesia 2009:pasal 128-129).

The compilation of Islamic Law and the Civil Code concerning joint property divided in two with the same amount shows that divorced husbands and wives have the same rights in terms of joint property distribution. This equal and fair distribution can be obtained if the husband and wife provide the same amount of contribution during the marriage. The husband carries out his obligations by earning a living outside the home and the wife carries out her obligations by taking care of the household, including taking care of the children and husband. However, there is not a few in a household that one of the parties does not provide an unequal contribution. Either the husband's contribution is greater than the wife's or the wife's contribution is greater than the husband's. In this case, there is only one party contributes in the process of collecting joint assets, while the 
others only become a burden on the other party.

Indonesia is a country that adheres to the supremacy of law, which means that all actions and decisions of state administrators must be based on law. Indonesia also adheres to the civil law tradition which prioritizes written law in the form laws and regulations. Therefore, every judge's decision in Indonesia must be based on written law. This aims to ensure the creation of legal certainty and avoid differences in decisions between one judge and another judge's decision.

The phenomenon of unequal contributions in the collection of joint property can be found in real life. We can find several cases of joint property that have been decided by the judge who handles the case of joint property. One example problem of joint property in a lawsuit that has been registered in a religious court is a husband sues his ex-wife against the distribution of joint property to be divided equally according to the provisions of the Compilation of Islamic Law and the Civil Code.

The wife gives her argument that the assets obtained during the marriage are the result of her hard work in which the wife is more dominant and plays an active role in meeting the needs of their household life. This can be seen from the persistence and efforts of the wife in fulfilling her household life, while the husband works with the help of his wife. In essence, the wife works in the household only to lighten the husband's burden, not as the backbone. The one who has the obligation to fulfill household life is still the husband as regulated in article 80 paragraph (4) letters a and b of the Compilation of Islamic Law which states that the obligation of a husband towards his wife is (1) a livelihood, kiswah and place of residence for the wife, (2) household expenses, maintenance costs and medical expenses for the wife and children.

From the laws and regulations in Indonesia, there are only KHI and Civil Code that regulate the distribution of joint property. Marriage Law no. 1 of 1974 does not even stipulate the exact distribution of this joint property. Article 37 of the UUP states that "if a marriage breaks 
up due to divorce, the joint property is regulated according to their respective laws. It is necessary to have a deeper interpretation of what each law means and how clear it is. Based on the background of the problem above, according to the author, several problems need to be raised and studied, namely, how to divide joint property according to the 1974 Marriage Law no. 1 and how joint property distribution based on the contribution of husband and wife in marriage from the distributive justice perspective is done by the judge.

\section{Research Method}

The type of research used is descriptive which means this research will be discussed in the form of an explanation described in words carefully and thoroughly (Waluyo 1996:15). In this case, the explanation of joint property in marriage is based on the Compilation of Islamic Law and the Civil Code; and its distribution is based on the contribution of husband and wife in the household.

The approach method used in this study is a normative juridical approach. Normative juridical approach means that the data analysis is based on legal principles and legal comparisons that exist in society (Soekamto 1986). Considering that the starting point of the research is the analysis of the laws and regulations related to joint property distribution after divorce.

\section{Discussion}

\section{Definition and Classification of Joint Property}

Joint property are assets acquired by husband and wife during marriage. In the acquisition of joint property, the wife is not obliged to collect joint assets, but she must carry out her obligations as a wife in married life (Mursyid 2014: 323). According to Talib, joint property is wealth obtained during marriage outside of gifts or inheritance. This means that the assets are obtained on their efforts, or individually during the period of the marriage (Thalib 1986:85). 
The definition of joint property in Article 35 of Law Number 1 of 1974 concerning Marriage is as follows: "Wealth acquired during marriage becomes joint property." In the Qur'an and Hadith there is no concept of joint property in marriage. Islamic law only recognizes the separation of property. The wife's property belongs to the wife and it is fully controlled by her, while the husband's property belongs to the husband and it is fully controlled by him.

In addition, the fiqh books do not discuss about joint property. The absence of a comprehensive discussion of joint property by the fuqaha' is acknowledged and this was due to the understanding of the Shari'a when the fiqh books were written in the state of the community structure at that time and they were not yet familiar with the concept of joint property (Arifin 1996:122).

In Indonesia, however, joint property is known through customary law which is applied continuously, from generation to generation as a living law. Therefore, the institution of joint property is impossible to get rid of because the benefits are greater than the harm. In the context of the shared assets, the benefits is the purpose of the joint property distribution. The wife is a worker in the husband's house and she deserves to be paid. The wages or the wife's hard work in the family certainly cannot be separated from the husband's property (Faizal 2015:92).

Joint assets are formed at the same time as the marriage, unless the parties specify in the marriage agreement in the form of separation of assets. This is reflected in Article 35 of the Marriage Law which confirms that property acquired during marriage becomes joint property (Harahap 1997:299).

The Civil Code also regulates when joint assets are formed. Article 119 Civil Code states that from the time the marriage takes place, according to the law, there is a complete joint property between husband and wife, as long as there are no other provisions in the marriage agreement. Thus, any assets obtained from the time the marriage contract is held until the marriage is terminated, whether due 
to divorce or death, then automatically become joint assets regardless of who the property was obtained from. (Wijayanti 2013:713).

However, there are some exceptions. If the property is in the form of inheritance, will or a grant received by one of the parties, the assets are counted as personal assets of each party and are fully controlled by them.

Until now, Indonesian people still have low understanding of the law related to legal issues. One of them is the problem of joint property. Many Indonesians think that all assets in a marriage automatically become joint property. This understanding is motivated by the assumption that with the occurrence of a marriage contract, it unites husband and wife in all aspects, including the issue of joint property. In fact, property in marriage includes inherited property, personal property and joint property which each has different legal statuses.

Regarding the joint property, it is still necessary to clearly classify which are the objects of joint property and which are not included in the joint property. Therefore, in order to find out how to determine the objects of joint property of husband and wife in marriage, it is necessary to describe the scope of joint property.

According to Law Number 1 of 1974 and the Compilation of Islamic Law, it is stated that the object of joint property is limited to assets acquired during marriage. But, according to Yahya Harahap, to determine the object of joint property is not that simple. According to him, the scope of joint property is as follows:

First is property purchased during marriage. Every item purchased during marriage is automatically, according to law, becomes the object of the joint property of husband and wife. Even if the property or goods are registered in the name of husband or wife, then the property in the name of the husband or wife is considered as joint property. Second is property that is proven obtained during the marriage. If the property is maintained/operated and has been transferred to the name of the husband's younger brother and the 
property can be proven that it is the results obtained during the marriage period, the property must be considered joint property of husband and wife. Third, assets purchased and built after a divorce are financed from joint property. Property or a house that is built or purchased after a divorce is considered joint property of husband and wife if the cost of building or purchasing an item is obtained from the joint venture during the marriage. Fourth is the income of joint property and inherited property. Income that grows from joint property automatically becomes the object of joint property. However, it is not only income that grows from shared assets, but also income that grows from personal property. In this case, the basic goods cannot be contested, but the results that grow from it fall into the object of joint property (Harahap 1997).

Regarding the provisions on the joint property distribution, Law Number 1 of 1974 concerning Marriage does not clearly regulate the provisions for joint property distribution. Article 37 states that: "If a marriage is dissolved due to divorce, joint property is regulated according to their respective laws." It can be interpreted what is meant by the respective laws in the explanation of Article 37 includes: "Religious law, customary law, and other laws."

The Compilation of Islamic Law clearly regulates the portion of joint property distribution. In particular, Article 97 states: "Divorced widow or widower is each entitled to one-half of the joint property as long as it is not specified otherwise in the marriage agreement." (Pemerintah Republik Indonesia 2008:pasal 97) .

According to what is formulated in the Compilation of Islamic Law, the application of the joint property distribution for each party to get half is an effort for legal unification, so that there are similarities in the decisions of religious court judges in deciding joint property cases.

In the Compilation of Islamic Law, the division on joint property upon divorce is divided in half, the same as the rules contained in Article 128 of the Civil Code that states: "After the dissolution of the joint property, their joint wealth is divided in half between husband 
and wife, or between their heirs, without questioning and to which party the goods came from." (Pemerintah Republik Indonesia 2009).

According to Yahya Harahap, the stance outlined in the Compilation of Islamic Law is in line with the orientation of the meaning of the partnership itself, so that husband and wife are considered as parties in partnership for joint property and deserve to get the same rights and shares if their marriage breaks up (Harahap 1997).

\section{The Effect of Contributions in Joint Property Distribution}

Changes in people's lifestyles occur slowly, but it surely will have a considerable impact on the emergence of changes in community values. Values that were once established experience a shift and undergo a new form of change and so on (Hakim 2015:119). For example, in the past, if a wife worked to earn a living outside the home to help the family, it could create a bad image in the eyes of society. But, now it is something that looks normal due to demands and changing times. The family economy is not only in the hands of the man or husband, but also the wife.

In addition, today's wife's income is also not just an additional or side economic source. Her income can even be the main source. Particularly in urban areas, we currently encounter many wives whose income becomes the economic foundation of the family, including her husband. It can be said that the wife has a double burden as a housewife and breadwinner. This makes a contribution gap between husband and wife in a household.

The division of joint property to be one-half for the husband and one-half for the wife will be felt in accordance with a sense of justice in terms of both husband and wife carrying out their respective responsibilities which can maintain the integrity and survival of the family (Dwisvimiar 2011). In this case, the consideration that husband or wife is entitled to half of the joint property is based on the role played by both husband and wife, as partners who complement each other in 
married life and are not biased.

If the wife does not work outside, but she still has a big role in a household, such as taking care of household matters, dropping off and picking up children, shopping and providing for her husband's needs, and so on, then the wife is worthy and has the right to get rights of half joint property. This is because the status of the wife who works at home as a housewife is as important as the status of her husband who works outside the home. On the other hand, when the wife works, while the husband does not carry out his proper role as wife's partner, the husband does not work hard and does not take care of the household, the division of joint property to be half for the wife and half for the husband is not in accordance with the sense of justice.

Based on this case, the interpretation of family law matters in the Compilation of Islamic Law, especially regarding the joint property distribution, needs to be appreciated so that both wife and husband get their rights fairly because the main pillar of law is justice. Based on this, the distribution of joint property based on the contribution of each husband and wife really needs to be appreciated in the context of upholding the principles of proportional justice between husband and wife in the eyes of the law.

\section{Joint Property Distribution in the Marriage Law}

With the enactment of the Marriage Law Number 1 of 1974 concerning marriage, the authority to adjudicate disputes over joint property for Indonesian citizens who are Muslim is a matter of dispute. This is because Article 35 and Article 36 of the Marriage Law do not explicitly state that disputes over joint property for Indonesian citizens who are Muslim are settled in the Religious Courts.

In fact, a signal of authority to the religious court to resolve the dispute has been given. This can be seen in article 37 which states: "if a marriage breaks up due to divorce, joint property is regulated according to their respective laws". This article should be interpreted in such a way that what is meant by the respective laws is religious law 
and customary law. If the person in the dispute is a Christian, the settlement of the case is according to his law, as well as if the person in the dispute is a Muslim, it will be resolved according to Islamic law. Since joint property disputes are included in customary law institutions, the authority remains with the district court even though the person in dispute is a Muslim. After the 1989 Law Number 7 regarding Religious Courts was launched on December 29, 1998, Article 49 paragraph 2 number 10 emphasizes that what is meant by the field of marriage as regulated in law number 1 of 1974 concerning marriage, among others, is the settlement of joint property disputes (Susanto 2011:156).

The Law on Religious Courts does not specifically explain joint property. Therefore, the explanation of joint property must be seen in the provisions of Articles, 35, 36, and 37 of Law Number 1974 concerning Marriage. The article only states what is included in joint property is property acquired during the marriage. In the event of a divorce, the marriage law does not clearly explain how much each husband and wife must receive from the joint property acquired during the marriage (Nagara 2016:53).

The provisions regarding the distribution and amount that husband and wife respectively receive from their joint property in the event of a divorce, whether divorced or widowed or the husband/wife is lost, can be seen in article 96 and article 97 of the Compilation of Islamic Law. Article 96 states "1) in the event of a divorce, half of the joint property becomes the rights of the spouse who lives longer; 2) the distribution of joint property for a husband or wife whose husband or wife is missing must be postponed until there is certainty of an essential death or legal death on the basis of a religious court decision.

Article 97 states: "Divorced widows or widower is each entitled to one-half of the joint property as long as it is not specified in the marriage agreement. The article above emphasizes that in the distribution of joint property between husband and wife who are divorced or widowed or because one of them is missing, each of them gets a half of the joint property. It does not take into account who 
works, and in whose name the joint property is registered. If the property is acquired during the marriage period, according to Article 35 and Article 36 of the Law, the acquired property is a joint property and can be divided between husband and wife.

The provisions of the articles above have shifted the provisions on the joint property distribution that are applicable in Indonesian society. The joint property distribution in Law no. 1 of 1974 concerning Marriage does not regulate the distribution clearly and definitely, but Article 37 states: "if a marriage is broken up due to divorce, the joint property is regulated according to their respective laws". What is meant by the respective laws in this article are religious law and customary law.

\section{Joint Property Distribution with Distributive Justice Perspective}

Several cases of joint property which have been decided by several judges at the religious court, give a fact that a wife has a double burden as a source of breadwinner as well as a housewife even though the responsibility for earning a living is a husband's obligation. It is also contained in Surah An-Nisa verse 34 which confirms that men are the protectors of women (wives) because Allah has prioritized men over women and because men provide a living from their wealth to women (wives). That way, if the wife's contribution is greater than the husband's, then the wife is entitled to a larger share of the husband.

The husband's obligation as the breadwinner is also regulated in Article 34 paragraph (1) of Law Number 1 of 1974 concerning Marriage that the husband is obliged to protect his wife and provide all the necessities of household life according to his ability. (Pemerintah Republik Indonesia 1974:Pasal 34). This provision is emphasized in Article 80 paragraph (4) of the Compilation of Islamic Law that according to his income the husband bears a living, kiswah, and a place of residence for the wife. When the husband does not carry out his obligations as breadwinner, it is necessary to ask whether the husband is entitled to get half of the joint property as stipulated in Article 97 of 
the Compilation of Islamic Law that states widow and widower get half of the joint property.

In practice, in court, to see various dispute cases, the first thing that a judge does is to first place the subject matter or the disputed case. After that, the judge will see how the relevant rules in the material law (such as the KHI and the Civil Code governing the distribution of joint property) are general and specific, either they are written or unwritten, to be measured with the case. The judge, then, will draw conclusions according to the evidence submitted and match the case (Eka Helmi interview).

In the case that is rarely found, it will bring consequences in terms of proof. This is the difficulty and responsibility of the judge to relate the facts or events, placing the case and using relevant evidence and law (Mursyid 2014). From this, it can be stated that the application of case law in the judiciary actually requires a very broad knowledge of material law. It is not and has not been sufficient to only master Islamic material law in legislation. Without it, finding material law in a case most likely does not reflect legal justice according to Islam.

The law on joint property distribution in the Compilation of Islamic Law (KHI) includes regulatory laws in the function of deductive, textual and normative laws. Meanwhile, the case for the joint property distribution submitted to the religious judge is casuistic, inductive, contextual and empirical, which is called a legal case. It must be acknowledged that changes in the socio-historical context in the joint property distribution are inevitable and will certainly occur because social life is dynamic and always changing. As a result, there are several laws that are left behind from these changes so that legal problems arise between the text and contextual. If we look at the case of joint property distribution based on the contribution of husband and wife, the provisions of the division described in the KHI and the Civil Code are no longer relevant. Therefore, for the sake of creating justice, judges can act contra legem (Adila 2020; Ristianawati 2020).

Contra legem is a court judge's decision that overrides existing 
laws and regulations, so that the judge does not use them as a basis for consideration or the decision even contradicts the article of law as long as the article of the law is no longer in accordance with the development and sense of community justice. This is allowed as the basis for Law Number 4 of 2004 Article 28 paragraph (1), states: "Judges are obliged to explore, follow, and understand legal values and a sense of justice that live in society." Meanwhile, Article 2 paragraph (1) of Law Number 48 of 2009 concerning Judicial Power states: "Judgments are carried out for the sake of justice based on the Almighty God." Likewise, Article 229 of the KHI states that judges in resolving cases submitted to them must pay serious attention to the legal values that live in society so that their decisions are in accordance with a sense of justice.

The judge's decision that is right and fair in the joint property distribution is a decision that decides the case of joint property distribution based on the services and contributions of the parties during the marriage. The decision of the panel of judges to act contra legem by giving more shares to the wife deserves to be appreciated. This is based on the consideration that there is a double burden for the wife as the breadwinner and housewife and the husband's minimal contribution to the acquisition of joint property during marriage, or vice versa. For instance, the husband becomes the backbone of the family to earn a living outside the home, but the wife does not carry out her obligations at all, such as taking care of household needs, caring for and taking for children, preparing husband's equipment and so on.

The concept of the joint property distribution based on contributions in marriage is in accordance with the theory of distributive justice from Aristotle (distributive justice) that states: "That justice is giving a share to each person based on his services or contributions". It can be interpreted that justice is dividing something proportionally, not dividing equally. For example, a manager who has a bigger contribution and responsibility than an office boy should get a bigger salary. That is what is called justice. If the salary of a manager whose contribution is greater is the same as that of an office boy, then that is injustice. Likewise in joint property, the wife who has a greater contribution than her husband should get a larger share of the joint 
property than her husband.

If we look at the rules of Islamic law, the field of ijtihad for mujtahids or including judges is if the Qur'an and Hadith do not regulate a particular case, or it already exists but it is still dzanny (less clear) or the law is inappropriate with a certain case due to sociohistorical changes in society, it is a gap as well as a duty for the mujtahid to seek ijtihad so as to find the rule of law (rechtsvinding).

As stated in the history of Islam, it happened at the time of the Prophet Muhammad SAW. Mu'ad Ibn Jabal was sent by the Prophet to be a judge to serve in Yemen. This is stated in the Hadith of the Prophet Muhammad SAW as follows: That when sending Muad to Yemen, the Prophet Muhammad SAW asked (to Mu'ad Ibn Jabal): "How will you judge or settle a dispute that comes to you? He replied: "I will refer to the (law) contained in Allah's book". The Prophet then asked: "If you do not find (the law) in Allah's book?" He replied: "Then, I will refer to the Prophet's Sunnah ". The Prophet asked: "If you don't find it in the Prophet's Sunnah or in Allah's book? He replied: "I will ijtihad with my mind and I will not be careless". Then the Prophet Muhammad SAW patted him on his chest and said: "Praise be to Allah who has given taufiq to the messenger of the Prophet Muhammad SAW who is blessed by the Prophet." (H.R. Abu Dawud).

From the Hadith, it can be understood that the judge must dig with his mind to find the law in handling the case he is handling, so that he can decide with a fair decision.

The concept of joint property distribution based on contributions in marriage provides space for judges to explore the values of justice in society and make decisions that reflect the values of substantive justice which is one of the constitutional messages in upholding the principle of justice in the judicial process. Judges are not only "la bauche de la loi" (the mouthpiece of the law), but the judge must also dig with his mind to find the law in handling the cases he handles, so that he can decide with a fair verdict. More concretely, this is manifested in court decisions which state: "For the sake of justice based on belief in the 
Almighty God" not "For Legal Certainty Based on Legislation" (Kurniawan 2017:75; Susilo 2019).

In the concept of joint property distribution based on contributions in marriage, the judge can decide on the joint property distribution to be one-half for the husband and one-half for the wife, if the husband and wife both contribute to the acquisition of joint property and each has completed the obligations that have been imposed by both. The husband is obliged to earn a living for his family. Likewise, the wife, in the case that the wife does not work outside, but she has a big role in maintaining the integrity and continuity of her family, such as taking care of household matters, dropping off and picking up children, shopping and providing for her husband's needs, and so on. Then, the wife deserves to get the right half of the common property. The status of a wife who works at home as a housewife is comparable to a husband who works outside the home (Mesraini 2012:69)

If the husband works for a living and the wife does not carry out her obligations to take care of the household, does not serve her husband, educate her children, even perform nusyuz for her husband, it means that the wife does not make a balanced contribution to her husband. In the event of a divorce, the husband is entitled to a larger share than the wife. It can be $2 / 3$ for the husband, while the wife only gets $1 / 3$ or $1 / 4$. On the other hand, if the wife who earns a living even takes care of the household, it gives a double burden for the wife. Meanwhile, if the husband does not actively carry out their obligations as breadwinners, and does not even want to know about household finances, in the event of a divorce, the wife is entitled to a larger share than the husband. It can be $2 / 3$ or $3 / 4$ for the wife while only $1 / 3$ or $1 / 4$ is for the husband.

Even in a case when the judge finds facts at trial that the husband does not carry out his obligations and he also causes trouble for the wife, commits domestic violence, is wasteful, often gambles or is drunk. The judge, then, may decide not to give a share of the joint property to the husband. 
So in the case of joint property distribution based on the contribution of husband and wife in this marriage, the judge can act contra legem which means setting aside the laws and regulations because they are not in accordance with current developments or in this case, the judge is obliged to explore new law. This action is done solely to provide justice between them. That justice should give everyone a share based on their services or contributions (Mertokusumo 2007). It can be concluded that the joint property distribution in marriage, when it is viewed from the perspective of justice, is the distribution of joint property by assessing the contribution of the parties. The fair distribution does not have to be $50 \%$ for widowers and $50 \%$ for widows. A husband can get a smaller share from his wife if his contribution is less during the marriage and he does not carry out his obligations as the breadwinner and the wife can get a larger share from the husband if the wife plays a dual role, and vice versa.

\section{Conclusion}

In the joint property distribution after divorce, the judge can override the provisions of the Compilation of Islamic Law Articles 97 and articles 128-129 of the Civil Code, if in the trial there are facts that can be considered by the judge in deciding the case which is about the contributions to marriage. In examining the case, the judge must see who has made the greater contribution during the married life. Then, the party with greater contribution is entitled to a larger share.

The concept of joint property distribution based on marriage contributions is inherent in the theory of distributive justice from Aristotle (justisia distributive), stating: "That justice is giving each person a share based on his services or contributions. In the sense that justice is dividing something proportionally, not dividing equally. The judge can divide based on each amount of the contribution between husband and wife. Here, if the wife contributes more to the collection

of joint assets, the wife's share will be greater than the husband's share 
and vice versa. In addition, judges are not only seen as mouthpieces of the law, but they are also required to have the courage to take decisions that are different from the normative law if the law is not in accordance with social changes in society. In the case of joint property in which one of the parties has a greater contribution, the judge is allowed to perform Contra legem so that in a case-by-case basis each party does not have to get a $50 \%$ share. It could be that the widower gets $25 \%$ and the widow $75 \%$ or whatever as long as the judge has carefully considered "for the sake of justice" for both parties. [w]

\section{References}

Adila, Arina Hukmu. 2020. "Sociological Aspects of Judges in Granting Applications for Marriage Dispensation (Study of Determination Number: 0038/Pdt. P/2014/PA. Pt).” Walisongo Law Review (Walrev) 2(2):159-68.

Arifin, Bustanul. 1996. Pelembagaan hukum Islam di Indonesia, akar sejarah hambatan dan prospeknya. Jakarta: Gema Insani Pres.

Dwisvimiar, Inge. 2011. "Keadilan dalam perspektif filsafat ilmu hukum.” Jurnal Dinamika Hukum 11(3).

Faizal, Liky. 2015. "Harta Bersama Dalam Perkawinan.” Itima’iyya $8(2)$.

Hakim, Dani Amran. 2015. "Politik hukum lingkungan hidup di Indonesia berdasarkan Undang-Undang Nomor 32 Tahun 2009 tentang Perlindungan dan Pengelolaan Lingkungan Hidup." Fiat Justisia Jurnal Ilmu Hukum 9(2).

Harahap, M. Yahya. 1997. Kedudukan kewenangan \& acara peradilan agama. Jakarta: Pusat Kartini.

Kurniawan, Muhamad Beni. 2017. "Konsep Pembagian Harta Bersama Berdasarkan Kontribusi Dalam Perkawinan.” AHKAM : Jurnal Ilmu Syariah 17(2). doi: 10.15408/ajis.v17i2.4741.

Mertokusumo, Sudikno. 2007. Mengenal Hukum: Suatu Pengantar. Yogyakarta: Liberty. 
Mesraini. 2012. "Konsep harta bersama dan implementasinya di pengadilan agama." Jurnal Ahkam 12(1):59-70.

Mursyid. 2014. "Ijtihad hakim dalam penyelesaian perkara harta bersama di Mahkamah Syariah Banda Aceh." Ar-Raniry: International Journal of Islamic Studies 1(2).

Nagara, Bernadus. 2016. "Pembagian Harta Gono-Gini Atau Harta Bersama Setelah Perceraian Menurut Undang-Undang Nomor 1 Tahun 1974." Lex Crimen 5(7):51-57.

Pemerintah Republik Indonesia. 1974. Undang-Undang No. 1 Tahun 1974 tentang Perkawinan.

Pemerintah Republik Indonesia. 2008. Kompilasi Hukum Islam.

Pemerintah Republik Indonesia. 2009. "Kitab Undang-Undang Hukum Perdata pasal 128-129 tentang harta bersama."

Ristianawati, Eka. 2020. "Interview with Helmi Ziaul Fuad, Judge of Pengadilan Agama Natuna."

Soekamto, Soerjono. 1986. Pengantar Penelitian Hukum. Jakarta: UI Press.

Susanto, Dedy. 2011. Kupas Tuntas Masalah Harta Gono-Gini. Yogyakarta: Pustaka Yustisia.

Susilo, Adhi Budi. 2019. "Renewal of Criminal Law Politics Relating to Justice Based On Justice.” Walisongo Law Review 2(2):157-74.

Thalib. 1986. Hukum Kekeluargaan Indonesia. Jakarta: UI Press.

Waluyo, Bambang. 1996. Penelitian Hukum dalam Praktek. Jakarta: Sinar Grafika.

Wijayanti. 2013. "Kedudukan istri dalam pembagian harta bersama akibat putusnya perkawinan karena perceraian terkait kerahasiaan bank." Jurnal Konstitusi 10(4). 